\title{
Mobilitet og sprogforandring
}

\author{
MALENE MONKA
}

Denne artikel beskæftiger sig med sammenhænge mellem mobilitet og sprogforandring i retning af mere standardnær sprogbrug. Hidtidige undersøgelser har kun haft adgang til optagelser med informanter, efter de har bevæget sig geografisk og socialt. Derfor kan de ikke give svar på, om årsagen til at de mobile informanter bruger færre lokale varianter end ikke-mobile informanter er, at de har bevæget sig geografisk og socialt, eller om de allerede brugte færre lokale varianter, før de flyttede. I artiklen præsenteres resultatet af den første undersøgelse, der har haft adgang til gamle og nye optagelser med de samme informanter. Undersøgelsen omfatter to grupper af informanter, én gruppe der har været geografisk og socialt mobil, og én der er blevet boende. Undersøgelsen er baseret på kvantitative analyser af udvalgte sprogtræk og kvalitative analyser af forhold knyttet til informanternes livshistorie og det sted, de er vokset op. Undersøgelsen viser, at de mobile informanter allerede som børn markerer sig sprogligt anderledes og benytter færre lokale varianter end de bofaste informanter. Ved at inddrage informanter fra tre forskellige dialektområder viser det sig, at sammenhænge mellem mobilitet og sprogforandring er mere komplekse end som så og blandt andet hænger sammen med det sted, informanterne kommer fra.

Emneord: mobilitet, sprogforandring, dialekt

Formålet med artiklen er at præsentere resultaterne af en undersøgelse af sammenhænge mellem mobilitet og sprogforandring i tre jyske kommuner. ${ }^{1}$ Undersøgelsen har som den første af sin slags haft mulighed for at undersøge denne sammenhæng ved at sammenligne gamle og nye optagelser med de samme informanter. Den ene del af informanterne har været både geografisk og socialt mobile, mens den anden er blevet boende i det lokalområde, hvor de er vokset op. Målet

1 Resultaterne er baseret på et ph.d.-projekt ved Afdeling for Dialektforskning, Københavns Universitet. 
har været at undersøge, om der er sammenhæng mellem mobilitet og ændring i retning af mere standardnær sprogbrug.

De hidtidige undersøgelser af mobile individers sprogbrug og -forandring er synkrone, dvs. de beskriver sprogbrugen på ét bestemt tidspunkt (Thelander 1985; Kerswill 1985, 1994; Mæhlum 1986; Omdal 1994; Røyneland 1994; Bowie 2000). Da man ikke tidligere har haft mulighed for at inddrage optagelser med de samme informanter, før og efter de har været mobile, har man været nødsaget til at undersøge sprogbrugen hos informanter, der har været mobile, uden at vide hvordan deres sprogbrug var tidligere. Eventuelle sammenhænge mellem mobilitet og sprogbrug er forsøgt konstateret vha. forskellige metoder: Ved at sammenligne mobile informanters sprogbrug $i$ to forskellige optagesituationer, hvor de taler med henholdsvis en lokalt og standardtalende interviewer, ved at sammenligne deres sprogbrug med en bofast kontrolgruppe, eller ved en kombination af disse metoder. Fælles for de synkrone studier er, at de finder klare sammenhænge mellem mobilitet og individers sprogbrug: Geografisk og social mobilitet hænger sammen med brugen af færre lokale træk og flere standardtræk.

Flere af de synkrone studier konkluderer imidlertid også, at der er nogle spørgsmål om kausalitet, som kun kan belyses vha. et diakront studie, hvor man følger de samme informanter over tid, dvs. et 'panelstudie i virkelig tid' (Bailey 2001: 329). Deltagerne, eller panelet, skal i det diakrone studie være sådan udvalgt, at alle informanter bor det samme sted på tidspunktet for første optagelse, og sådan at nogle har været mobile på tidspunktet for den anden optagelse, imens andre har været bofaste. Ved at foretage sammenlignende kvantitative analyser af udvalgte sprogtræk hos de to grupper, kan man således komme nærmere på at beskrive, hvordan mobilitet og sprogforandring hænger sammen. For det første kan man svare på, om eventuelle ændringer i sprogbrug skyldes mobilitet, eller om de bofaste informanters sprogbrug også har ændret sig (Omdal 1994: 34; Andersson \& Thelander 1994: 58). For det andet kan man undersøge, om de mobile informanter allerede taler mindre lokalt end de bofaste, før de flytter (Bowie 2000: 143), så det ikke er den geografiske og sociale mobilitet alene, der medfører sprogforandring. Nogle af de synkrone mobilitetsstudier peger desuden på, at det er nødvendigt at foretage kvalitative analyser af en række forhold 
i den enkeltes livshistorie for at forklare sammenhænge mellem mobilitet og sprogbrug (Omdal 1994; Andersson \& Thelander 1994).

I det følgende præsenteres resultaterne af et panelstudie i virkelig tid, der ved hjælp af kvantitative og kvalitative analyser belyser ovennævnte ubesvarede spørgsmål om sammenhænge mellem mobilitet og sprogforandring. I undersøgelsen indgår 23 informanter fra Odder, Vinderup og Tinglev Kommuner. ${ }^{2}$ Som man kan se på kortet, ligger de tre kommuner $\mathrm{i}$ tre forskellige jyske dialektområder.

FIGUR 1: ODDER, VINDERUP OG TINGLEV KOMMUNER INDPLACERET I HENHOLDSVIS DET ØST-, VEST- OG SØNDERJYSKE DIALEKTOMRÅDE (KORT: ANETTE JENSEN).

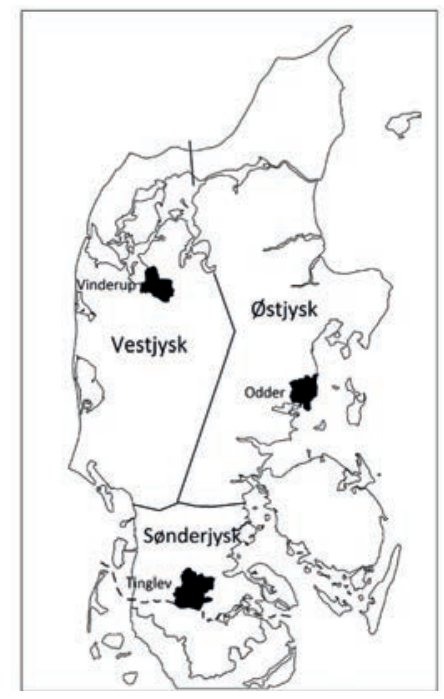

I relation til resultaterne af tidligere studier er det ikke overraskende, at undersøgelsens kvantitative analyser viser, at ingen af de mobile informanter bruger dialekttræk, efter de har været geografisk og socialt mobile. Mere overraskende viser analyserne, at de mobile informanter taler mindre lokalt end de bofaste informanter med samme sociale baggrund, allerede for de flytter. Analyserne viser imidlertid også store forskelle i sprogforandringen på sted- og individniveau såvel blandt mobile som bofaste informanter. For at forsøge at forklare de fundne

2 Her er tale om kommunegrænser før Kommunalreformen af 2007. 
forskelle er der udført kvalitative analyser af en række forhold knyttet til hver lokalitet og til den enkelte informants livshistorie.

I det følgende gennemgår jeg, hvordan mobilitet er operationaliseret i undersøgelsen samt hvilke typer af data, der indgår. Dernæst præsenterer jeg resultaterne af undersøgelsens kvantitative analyser, der fokuserer på udvalgte sproglige træk. Til sidst præsenterer jeg resultaterne af de kvalitative analyser, der søger at forklare de fundne sprogforandringsmønstre ved at fokusere på omstændigheder knyttet til den enkelte informants livshistorie og den enkelte lokalitet.

\section{TRE FORMER FOR MOBILITET}

Igennem de seneste år har der været en stigende videnskabelig interesse for mobilitet; nogle taler ligefrem om et 'mobility turn' inden for samfundsvidenskab (Adey 2009; Urry 2007). Den øgede interesse forklares blandt andet med den tiltagende globalisering, der medfører, at mennesker og varer bevæger sig i et hidtil uset omfang og over større afstande end tidligere (se fx McIllvenny et al. 2009; Cresswell 2006). Inden for sprogforskning er sammenhængen mellem geografisk mobilitet og sprogforandring blevet undersøgt på forskellige niveauer, lige fra individers hverdagsmobilitet (fx Milroy 1980; Britain 2013), over dannelsen af nye industribyer (fx Kerswill \& Williams 2000; Solheim 2006; Mæhlum 1992), til flytning mellem kontinenter og konsekvenser af kolonialismen (fx andetsprogsforskning samt forskning i kreol- og pidginsprog). Der er også udført undersøgelser af sammenhænge mellem social mobilitet og sprogforandring (fx Labov 1967; Mees \& Collins 1999). Trods vidt forskellige skalaer og fokus på forskellige former for mobilitet er der bred enighed blandt sprogforskere om, at mobilitet er en af de vigtigste årsager til sprogforandring hos såvel individer som i sprogsamfund (Chambers 2002: 117). Alligevel er der - ironisk nok og med visse undtagelser (jf. ovenfor) - foretaget forholdsvis få undersøgelser af sammenhænge mellem geografisk og social mobilitet og dialektforandring. Det skyldes formodentlig, at mobilitet forstyrrer klassiske dialektologers og variationistiske sociolingvisters primære studieobjekt, der henholdsvis er den traditionelle dialekt, som den tales blandt bofaste informanter $\mathrm{i}$ et geografisk afgrænset - ofte ruralt - 
område, og sproglig variation mellem forskellige grupper tilhørende ét - ofte urbant - sted. Og det betyder, at mobile individer er blevet fravalgt i undersøgelserne. Fokus i min undersøgelse er derimod netop på, hvad der sker med menneskers sprogbrug, når de som rigtig mange andre i den moderne verden bevæger sig geografisk og socialt.

For at belyse de hidtidige hypoteser om sammenhænge mellem mobilitet og sprogbrug bedst muligt skelner jeg i undersøgelsen mellem geografisk, social og mental mobilitet. De tre former for mobilitet defineres og bruges på følgende måde i artiklen: Geografisk mobilitet defineres som det at flytte fra sin hjemegn og ikke længere opretholde daglig ansigt til ansigt-kontakt med mennesker derfra (Andersen 2010: 13). Social mobilitet defineres som det at tage en længere uddannelse end sine forældre (Munk 2003: 9). Mental mobilitet defineres som det at være orienteret mod en urban livsstil samt ønsket om at bo et andet og mere urbant sted og/eller ønsket om at tilhøre en højere socialgruppe. Mental mobilitet er mindre undersøgt end geografisk og social mobilitet. Og til trods for at diskussioner af mental orientering indgår i enkelte tidligere sociolingvistiske studier, er betegnelsen 'mental mobilitet' ikke brugt i disse. Labov viste fx allerede i sin første undersøgelse (1967), at de informanter fra øen Martha's Vineyard, der orienterede sig mod fastlandet, talte mindre lokalt end dem, der ønskede at blive boende på øen. Senere har andre undersøgelser vist, at geografisk og social orientering mod mere urbane steder og højere socialgrupper påvirker sprogbrug i retning af standardnær sprogbrug (se fx Hårstad 2010; Mees \& Collins 1999).

Hvis der som i mit studie er tale om frivillig mobilitet, hvor informanterne bevæger sig geografisk for at tage en højere uddannelse, er det rimeligt at antage, at de tre mobilitetsformer hænger sammen, $i$ den forstand at informanterne formodentlig ikke ville være blevet geografisk og socialt mobile, uden at de på forhånd havde været mentalt mobile. Eftersom der har været tale om en generel mental urbanisering af den danske befolkning (I.L. Pedersen 1994: 87) - også blandt folk bosat på landet - er der ingen af mine informanter, der har været mentalt immobile eller upåvirkede af den urbane livsstil, ej heller blandt de bofaste. Som jeg vil vise i de kvalitative analyser nedenfor, er der imidlertid tale om vigtige gradsforskelle mellem informanterne, og det skal 
understreges, at man godt kan være mentalt mobil og orientere sig mod andre socialgrupper eller steder, uden at man nødvendigvis bevæger sig socialt eller geografisk.

Geografisk og social mobilitet kan konstateres vha. flytteafstand og social bevægelse, hvorimod mental mobilitet kun kan konstateres vha. kvalitative analyser af, hvordan den enkelte orienterer sig i sit hverdagsliv samt vedkommendes eventuelt eksplicitte kommentarer om geografisk og social orientering fremsat $\mathrm{i}$ interviewsituationer eller lignende. For sprogforskere er det interessante ved de tre mobilitetsformer, at de enten indebærer kontakt med mennesker fra andre steder og samfundslag eller orientering mod disse, og at det kan påvirke både individers og sprogsamfunds sprogbrug.

\section{DATA}

Undersøgelsens informanter blev optaget første gang i 14-20-årsalderen i perioden 1978-1989 og igen i 2005-2010. De tidligere undersøgelser fra Odder (Nielsen \& Nyberg 1988, 1989, 1992, 1993) og Vinderup (Kristensen 1980) blev foretaget af forskere ved Afdeling for Dialektforskning og de senere af medarbejdere ved Danmarks Grundforskningsfonds Center for Sociolingvistiske Sprogforandringsstudier (Gregersen et al. 2005; Gregersen \& Kristiansen 2015). Både de gamle og nye Tinglev-optagelser er foretaget af K.M. Pedersen, Institut for Grænseregionsforskning, der siden 2004 har været tilknyttet Syddansk Universitet (K.M. Pedersen 1986, 2004).

I min undersøgelse indgår fem mænd og fire kvinder fra Odder Kommune, seks mænd og fire kvinder fra Vinderup Kommune samt to mænd og to kvinder fra Tinglev Kommune. Da de første optagelser blev lavet, boede de alle sammen i én af de tre kommuner; da de nye optagelser blev lavet havde én mand og én kvinde fra hvert sted været geografisk og socialt mobil. Studiet omfatter således seks mobile og 17 bofaste $^{3}$ informanter. I de analyserede data taler informanterne med

3 Informanterne boede i deres opvækstkommune, da de nye optagelser blev lavet. Enkelte af disse har været bortrejst fra hjemkommunen i kortere eller længere perioder, hvilket har haft forskellig betydning for deres sprogbrug (se Monka 2013 kap. 9). 
en interviewer, der taler standardnært ${ }^{4}$. De gamle optagelser er mellem 7 og 30 minutter lange og forholdsvis formelle, de nye optagelser er mere uformelle sociolingvistiske interview på cirka halvanden time. Ud fra den viden vi har fra dansk dialektforskning og sociolingvistik, ville den ideelle informant $i$ min undersøgelse principielt være en informant med landbrugsbaggrund, der er flyttet til København for at tage en akademisk uddannelse. På den måde ville informanten være flyttet til Danmarks sproglige normcenter (Kristiansen 2009), hvorfra alle sproglige nyudviklinger er udgået fra siden 1960'erne (I.L. Pedersen 2009a), og samtidigt have bevæget sig væk fra den socialklasse, dialekt traditionelt har været stærkest tilknyttet, og i retning mod den socialklasse standardsproget typisk associeres med. Oversigten i Tabel 1 over de seks mobile informanter i mit studie viser, at ingen af dem kan siges at være den helt ideelle informant, ud fra de parametre som er diskuteret her.

TABEL 1: OVERSIGT OVER DE MOBILE INFORMANTERS BAGGRUND OG MOBILITET

\begin{tabular}{lllll}
\hline Informant & Opvokset i Flyttet til & $\begin{array}{l}\text { Forældres } \\
\text { beskæftigelse }\end{array}$ & $\begin{array}{l}\text { Informantens } \\
\text { uddannelse }\end{array}$ \\
\hline Lone & Odder & $\begin{array}{l}\text { By 40 km fra } \\
\text { København }\end{array}$ & Gartneri-ejere & Kemiingeniør \\
\hline Klaus & Odder & $\begin{array}{l}\text { By 25 km fra } \\
\text { København }\end{array}$ & Landbrugere & Cand.scient. \\
\hline Lisa & Vinderup & København & Landbrugere & Sygeplejerske \\
\hline Mads & Vinderup & Odense & Landbrugere & Civiløkonom \\
\hline Eva & Tinglev & $\begin{array}{l}\text { By 10 km fra } \\
\text { København }\end{array}$ & Lærere & Cand.mag. \\
\hline Søren & Tinglev & Sønderborg & Landbrugere & Ingeniør \\
\hline
\end{tabular}

Det er kun Lisa fra Vinderup, der er flyttet til København, imens fire andre bor inden for en radius af $40 \mathrm{~km}$ fra hovedstaden. Sammen med Klaus fra Odder, Mads fra Vinderup og Søren fra Tinglev, lever Lisa også op til idealet om landbrugsbaggrund. Til gengæld er hun den ene-

4 Når intervieweres sprogbrug omtales som 'standardnært' er det for at understrege, at der er tale om en sprogbrug, der ikke opfattes som lokal af informanterne, men enten som umarkeret, "fint" eller "rigsdansk" afhængig af den enkelte lokalitet (for yderligere diskussion se Monka 2013 kap. 5). 
ste af de mobile informanter, der ikke har taget en lang videregående uddannelse; sygeplejerstudiet er en mellemlang uddannelse normeret til tre et halvt år. Når de seks informanter alligevel indgår i studiet, er det fordi de kommer tættest på idealerne blandt de informanter, der findes optagelser med. I et panelstudie i virkelig tid kan man som sagt kun inddrage informanter, der er optaget på to forskellige tidspunkter, og det er derfor ikke muligt at gå tilbage og finde 'den ideelle informant' med tilbagevirkende kraft. Og manglerne til trods viser de kvantitative resultater klare sammenhænge mellem informanternes mobilitet og sprogbrug, hvilket viser, at man ikke behøver at finde den ideelle informant for at finde interessante effekter.

\section{SPROGLIGE VARIABLE OG KVANTITATIVE RESULTATER}

De kvantitative analyser tager afsæt i fonologiske og morfologiske variable, som de tidligere undersøgelser har udpeget som særligt relevante for den aldersgruppe, informanterne tilhører, på de pågældende steder (se detaljer nedenfor). For hver af variablene er der kodet 32 forekomster $^{5}$, herefter er der beregnet et gennemsnit, der angiver et procenttal for de lokale varianter. Når den mobile Eva fra Tinglev fx har $0 \%$ af variablen JEG, betyder det, at hun ikke bruger den sønderjyske variant ("æ") af det personlige pronomen JEG i det analyserede interview. For hver informant har jeg beregnet en samlet 'dialektprocent' i de gamle og nye optagelser. Den er beregnet ved at lægge procenttallene for de enkelte variable sammen og dividere med antallet af variable. Informanternes sprogforandring er således konstateret ved at sammenligne deres dialektprocent i de gamle og nye optagelser. Dialektprocenten giver på denne måde et overordnet indtryk af informanternes sprogbrug og individuelle sprogforandring (for udviklingen af enkeltvariable se Monka 2013: 78-112). Idet der er tale om forskellige sproglige variable de tre steder, kan dialektprocenterne ikke sammenlignes direkte på tværs af indsamlingsstederne, men man kan undersøge, om udviklingen går i samme retning.

5 Antallet er inspireret af Schønings og I.L. Pedersens undersøgelser af sprogforandring i Vinderup (2009), og lægger sig mellem de 20 og 50 forekomster som henholdsvis Maegaard (2007: 82) og Eckert (2000: 87) koder for. 


\section{Odder}

Da Nielsen og Nyberg undersøgte sprogbrugen i Odder i slutningen af 1980'erne, var den traditionelle dialekt allerede forsvundet (1992: 180). Det betyder, at de undersøgte variable ikke er dialektale, men regionale, idet de er udbredt $\mathrm{i}$ et større geografisk område, herunder den nærmeste storby Århus (Nielsen \& Pedersen 1991; Nielsen 1998; for OR, -ET og SÅDAN se også Petersen 2013). Derfor omtales beregning af lokale variable i Odder som informanternes 'regionalstandardprocent'. Følgende variable blev udpeget som særligt relevante for at beskrive informanternes sprogbrug i 1986 (Nielsen \& Nyberg 1992: 92):

TABEL 2: VARIABLE DER INDGÅR I DE KVANTITATIVE ANALYSER I ODDER.

\begin{tabular}{|c|c|c|c|}
\hline Variable & Beskrivelse & Standard & Regional \\
\hline BLØDT d & $\begin{array}{l}\text { Udtalen af }-d \text { i ord hvis } \\
\text { standardvariant i trykstærke } \\
\text { stavelser er [ð], fx i rodgrod og } \\
\text { flode. }\end{array}$ & $-\partial$ & $-i,(\partial-)$, nul \\
\hline OR & $\begin{array}{l}\text { Udtalen af skriftens -or i visse } \\
\text { ord, for eksempel skjorte og } \\
\text { tror. }\end{array}$ & $\mathrm{O}(\cdot) \cdot 1$ & $\grave{a}(\cdot), \mathrm{a}(\cdot)$ \\
\hline -ET & Udtalen af -et undtagen i meget. & $-\partial ð$ & $-\partial t,(-\partial d)$ \\
\hline -ET i meget & Udtalen af -et i meget. & $-\partial ð$ & $-\partial t,(-\partial d)$ \\
\hline -EDE & $\begin{array}{l}\text { Udtalen af -ede i præteritum } \\
\text { (for eksempel startede). }\end{array}$ & $\begin{array}{l}-\partial \\
\text { (stavelsesdannende } \\
\text { eller efterfulgt af } \\
\text { [ə]) }\end{array}$ & $-\partial t,(-\partial d)$ \\
\hline DEN/DET & $\begin{array}{l}\text { Enklitisk den og det efter } \\
\text { pronomener, præpositioner og } \\
\text { verber. }\end{array}$ & $-d n /-d e$ & $-(\partial) n /-\partial t$ \\
\hline SÅDAN & Udtalen af saidan. & sodn, son'n & so.' $n$ \\
\hline OGSA & Udtalen af også. & $\partial s(\partial)$ & 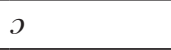 \\
\hline
\end{tabular}

Den mobile Lones regionalstandardprocent er 25,4 i 1986, den udgøres primært af $100 \%$ regionale varianter af OR og $67 \%$ regionale varianter af -ET. I 2008, hvor hun har været geografisk og socialt mobil, er hendes regionalstandardprocent 19,6, og den udgøres primært af regionale varianter af OR og -ET (henholdsvis 88 og 59 \%). Klaus' regionalstandardprocent er 46,4 i 1986, og der er manifestationer af alle 
de undersøgte regionale varianter på nær OGSÅ i hans sprogbrug. I 2006 er hans regionalstandardprocent faldet til 12,9 og udgøres næsten udelukkende af regionale varianter af OR (91\%).

Lones og Klaus' sprogbrug har altså ændret sig, efter de har været geografisk og socialt mobile. Men geografisk og social mobilitet er ikke den eneste årsag til den fundne sprogforandring. De kvantitative analyser viser for det første, at Lone og Klaus allerede i 1986 bruger færre regionale varianter end bofaste informanter af samme køn og sociale baggrund, og for det andet at de bofaste informanters sprogbrug også har ændret sig $^{6}$. Således sker der et fald fra 55,3 til 37,8 procentpoint $i$ de bofaste kvinders regionalstandardprocent og et fald på 59,2 til 52,3 procentpoint i de bofaste mænds regionalstandardprocent mellem de to optagetidspunkter.

\section{Vinderup}

Kristensen har beskrevet sprogsamfundet i Vinderup i flere undersøgelser $(1977,1979,1980)$. I min undersøgelse indgår informanter, der blev optaget i 1978, da de gik i 8. klasse. Formålet med den oprindelige undersøgelse var at undersøge, om informanterne benyttede situationsafhængig sprogbrug; det blev gjort ved at fokusere på de variable, som er opført i Tabel 3.

TABEL 3: VARIABLE DER INDGÅR I DE KVANTITATIVE ANALYSER I VINDERUP.

\begin{tabular}{|c|c|c|}
\hline Variable & Beskrivelse & Standard Dialekt \\
\hline V-STØD & $\begin{array}{l}\text { Vestjysk stød undtagen i ikke. Vestjysk stød } \\
\text { findes umiddelbart foran klusilerne p, t og k, } \\
\text { hvor disse er i oprindelig indlyd efter stemt } \\
\text { lyd i trykstærk stavelse. Vestjysk stød findes } \\
\text { også i ord, hvor p, t og k er kommet i udlyd } \\
\text { på grund af en senere apokope (Ringgaard } \\
\text { 1960: 10). }\end{array}$ & $\begin{array}{l}\text { For } \quad h 0^{\prime} p, \\
\text { eksempel: } k j a ̈ i k \\
\text { hoppe vb., } \\
\text { kirke sb. }\end{array}$ \\
\hline IKKE & $\begin{array}{l}\text { Vestjysk stød i ikkee (også når det står } \\
\text { enklitisk) }\end{array}$ & ega, eg \\
\hline
\end{tabular}

6 Det bør understreges, at gennemsnittet for de bofaste informanter fra Odder, Vinderup og Tinglev dækker over store inter-individuelle forskelle i sprogbrug og -forandring (se Monka 2013 kap. 9). Ikke desto mindre kan gennemsnittet være med til at illustrere, at mobilitet ikke er den eneste årsag til sprogforandring. 


\begin{tabular}{|c|c|c|c|}
\hline KLUSIL & $\begin{array}{l}\text { Klusilspring. I oprindelige enstavelsesord } \\
\text { med langt i, u og y forekommer en parasitisk } \\
\text { klusil i stedet for det fællesdanske stød. }\end{array}$ & $\begin{array}{l}\text { For } \\
\text { eksempel: } \\
\text { tid sb., lys } \\
\text { adj./sb., } \\
\text { bus sb. }\end{array}$ & $\begin{array}{l}\text { tik, } \\
\text { lyks, } \\
\text { huks }\end{array}$ \\
\hline$\overline{\mathrm{EE}}$ & $\begin{array}{l}\text { Udtalen af standardsprogets lange e er } \\
\text { diftongeret til [iə] i ord som hel og ben, } \\
\text { og til kortdiftongen [jæ] i talordet en og i } \\
\text { sammensætninger som benstump og stendynge. }\end{array}$ & $\begin{array}{l}\text { For } \\
\text { eksempel: } \\
\text { ben sb., én } \\
\text { num. }\end{array}$ & $\begin{array}{l}\text { bi’on, } \\
\text { jan' }\end{array}$ \\
\hline$\overline{\mathrm{OO}}$ & $\begin{array}{l}\text { Udtalen af standardsprogets lange o er i } \\
\text { forlyd diftongeret til kortdiftongen [wo] i ord } \\
\text { som for eksempel ost og orm. I indlyd som i } \\
\text { for eksempel kone er udtalen [uə], og i udlyd } \\
\text { som for eksempel i bro er udtalen [å }{ }^{\prime} \text { ]. }\end{array}$ & $\begin{array}{l}\text { For } \\
\text { leksempel: } \\
\text { orm sb., } \\
\text { kone sb. } \\
\text { sing., bro } \\
\text { sb. }\end{array}$ & $\begin{array}{l}\text { wo.tm, } \\
\text { ku’zn, } \\
\text { bråw' }\end{array}$ \\
\hline \multicolumn{2}{|c|}{ ARTIKEL Foranstillet artikel } & $\begin{array}{l}\text { Huset/ } \\
\text { hunden }\end{array}$ & $\begin{array}{l}\text { æ hus } / æ \\
\text { hund }\end{array}$ \\
\hline$\overline{\mathrm{JEG}}$ & Personligt pronomen & jeg & $\mathrm{a}$ \\
\hline
\end{tabular}

Kristensen fandt i øvrigt kun én pige, der kodeskiftede nævneværdigt mellem to forskellige situationer, og hun indgår ikke i denne undersøgelse.

Der er flere interessante pointer at udlede af de kvantitative analyser fra Vinderup. Den vigtigste er, at geografisk og social mobilitet ikke kan være forklaringen på den fundne sprogbrug og -forandring. Analyserne viser nemlig, at de mobile Vinderup-informanter slet ikke brugte nogen af de undersøgte dialektvarianter i 1978, og de gør de heller ikke i 2006, dvs. deres dialektprocent er 0,0 i begge optagelser. Analyserne viser også, at Lisa og Mads allerede i 1978 markerede sig markant anderledes end informanter, der blev bofaste. Således var den samlede dialektprocent for de bofaste kvinder og mænd henholdsvis 67,2 og 36 i 1978. At de bofaste kvinders dialektprocent er faldet til 42,4 og mændenes til 29,5 i 2006 viser tydeligt, at forklaringen på sprogforandringen skal findes et andet sted end i mobilitet.

\section{Tinglev}

K.M. Pedersens oprindelige undersøgelse i Tinglev omfattede børn og unge i de danske og tyske børnehaver og skoler. Interviewene, der indgår i denne undersøgelse, blev lavet, da informanterne gik i 9. klasse på 
den danske skole i 1986. Dengang var de dialektvarianter, der angives i Tabel 4 særligt relevante for at beskrive deres sprogbrug (K.M. Pedersen 1986: 61f.; Nyberg 1991: 161).

TABEL 4: VARIABLE DER INDGÅR I DE KVANTITATIVE ANALYSER I TINGLEV.

\begin{tabular}{llll}
\hline Variable & Beskrivelse & Standard & Dialekt \\
\hline EE & $\begin{array}{l}\text { Udtalen af standardsprogets lange e er } \\
\text { diftongeret, for eksempel i se og bele. }\end{array}$ & $e$. & $e^{i}$ \\
\hline OO & $\begin{array}{l}\text { Udtalen af standardsprogets lange o er } \\
\text { diftongeret, for eksempel i bro og skole. }\end{array}$ & $o$ & $o^{w}$ \\
\hline B til F & $\begin{array}{l}\text { Udtalen af gammeldansk p i udlyd og } \\
\text { mellem vokaler, for eksempel i skib og } \\
\text { gabe. }\end{array}$ & $b$ & $f$ \\
\hline G til CH & $\begin{array}{l}\text { Udtalen af gammeldansk k i udlyd og } \\
\text { mellem vokaler nærmer sig den tyske } \\
\text { udtale af det skrevne ch (fx i ich eller } \\
\text { nach), den findes fx i bog og bage. }\end{array}$ & $q$ & $x$ \\
\hline ARTIKEL & Foranstillet artikel & huset/ \\
\hline JEG & Personligt pronomen & $\mathfrak{x}$ hus/æx \\
\hline IKKE & Ikke $=$ it & jeg & $\mathfrak{x}$ \\
\hline
\end{tabular}

K.M. Pedersen fandt, at der på trods af få nydannelser var børn, der beherskede dialekten i 1986, desuden fandt hun en udbredt brug af situations- og samtalepartnerafhængig kodeskift (1986: 185). Og i modsætning til i Vinderup, viser Nyberg (1991), at de unges brug af udvalgte standarddanske varianter, når de taler med en ikke-lokal interviewer, er ens uanset social baggrund. Den eneste signifikante forskel mellem land- og by-informanternes sprogbrug $\mathrm{i}$ interviewene er, at land-eleverne bruger flest dialektale varianter af OO (Nyberg 1991: 163). I 1986 havde Eva en dialektprocent på 0,9 og i 2009 var den 0. Sørens dialektprocent er forandret fra 67,3 i 1986 til 0 i 2010. Allerede i 1986 markerer Eva og Søren sig sprogligt anderledes end de to bofaste informanter, hvor den bofaste Pia havde en dialektprocent på 2,7 og den bofaste Niels en dialektprocent på 93,4. I de ny optagelser er der sket en lille stigning i Pias og Niels' dialektprocent til henholdsvis 9 og 97,9 procentpoint. Den lave dialektprocent hos de to kvindelige Tinglev-informanter i 1986 dækker i øvrigt over, at de begge kodeskif- 
ter i samtale med den ikke-lokale interviewer. Der foreligger således optagelser med dem begge med sønderjysktalende interviewer, hvor de begge benytter alle dialektvarianter på nær IKKE.

Med hensyn til spørgsmålet om hvorvidt geografisk eller social mobilitet er den vigtigste faktor for sprogforandring, er det værd at bemærke, at den markante forandring i Sørens sprogbrug er sket, til trods for at der $i$ hans tilfælde kun er tale om geografisk mobilitet over en kortere afstand (ca. 40 kilometer). Ved at flytte til Sønderborg er han ikke alene blevet inden for det sønderjyske dialektområde, han er også flyttet til en by med egen by-dialekt (ifølge Nielsen \& Pedersen 1991). Derfor kan man konkludere, at årsagen til Sørens sprogforandring formentlig skal tilskrives hans sociale mobilitet og den sprogbrug, der efter hans opfattelse er passende i den forbindelse, hvilket vi skal se nærmere på i det følgende.

\section{SAMLET RESULTAT AF DE KVANTITATIVE ANALYSER}

I tråd med tidligere mobilitetsstudier viser mine kvantitative analyser klare sammenhænge mellem geografisk og social mobilitet på den ene side og brugen af snævert distribuerede dialekttræk på den anden. Der er således ingen af de mobile informanter, der bruger dialekttræk i interviewene, efter de har været mobile. Desuden viser undersøgelsen ligesom de synkrone studier, at nogle varianter, der er udbredt over et større geografisk område - som OR og -ET i Odder - stadig forefindes i de mobile informanters sprogbrug (jf. Omdal 1994: 122; Thelander 1979: 112-119; Ivars 1986: 172-179).

På grund af den diakrone metode kan min undersøgelse imidlertid også i et vist omfang besvare de spørgsmål om kausalitet, som de hidtidige, synkrone studier ikke kan. Det mest overraskende resultat af analyserne er, at de mobile informanter markerer sig sprogligt anderledes end deres bofaste kammerater, allerede før de forlader deres hjemegn. Undersøgelsen viser desuden tydeligt, at mobilitet ikke er den eneste årsag til sprogforandring. I Odder og Vinderup sker der nemlig større sprogforandringer hos den bofaste kontrolgruppe end hos de mobile informanter. 
Et andet overraskende fund er, at sprogforandringen tager sig vidt forskelligt ud blandt de bofaste informanter fra de tre kommuner. I Odder er regionalstandardprocenten faldet, i Vinderup er dialektprocenten faldet, især blandt de kvindelige informanter, og i Tinglev er dialektprocenten steget en smule. Idet resultaterne kun gælder sprogforandringen hos én aldersgruppe og forholdsvis få individer fra hvert sted, er det værd at nævne, at resultaterne understøttes af studier af unges sprogbrug i de tre kommuner. I 2005 benytter unge i 9. klasse i Odder således en del regionale varianter, om end færre end forældregenerationen, mens de unge i Vinderup benytter forsvindende få dialektvarianter (Shøning \& Pedersen 2007). Og et igangværende studie i Bylderup - ti kilometer fra Tinglev - omfatter en del unge, der bortset fra dialektvarianten af IKKE, benytter alle de dialektvarianter, der anføres i Tabel 4 (se www.nfi.ku.dk/lapur og www.nfi.ku.dk/dpef). Sprogforandringen gælder således tilsyneladende ikke blot individer, men også sprogsamfundet. For at forsøge at forklare de fundne sprogforandringsmønstre har jeg foretaget kvalitative analyser af en række forhold på individ- og sprogsamfundsniveau.

\section{KVALITATIVE ANALYSER PÅ INDIVIDNIVEAU}

På baggrund af kvalitative analyser på individniveau kan jeg ligesom de synkrone mobilitetsstudier konkludere, at køn, alder, etnicitet og socialgruppetilhørsforhold ikke er tilstrækkelige til at forklare sprogforandring i forbindelse med mobilitet (jf. Omdal 1994: 224). Det konkluderer jeg blandt andet, fordi alle de mobile informanter kan sammenlignes med én eller flere bofaste informanter, der på tidspunktet for de første optagelser er ens mht. alder, køn og etnicitet - men altså ikke sprogbrug. Derudover har Lisa fra Vinderup og Søren fra Tinglev dét, man kunne kalde en sociologisk tvilling, som ud over samme alder, køn og etnicitet også har samme sociale baggrund, men som er blevet boende, og hvis sprogbrug og -forandring er helt anderledes.

De kvalitative analyser viser, at én af forklaringerne på de mobile og bofaste informanters forskellige sprogbrug sandsynligvis er forskelle mellem deres geografiske og sociale orientering i barndommen, dvs. i deres mentale mobilitet. Det ses blandt andet i de nedenstående ud- 
drag fra interview med Tinglev-informanterne, Søren og Niels, da de var 14 år. I uddragene fremgår det, at Søren og Niels har forskellige forestillinger om, hvad de gerne vil være, samt forskellige opfattelser af hvorvidt det indebærer et behov for at lære 'rigsdansk'. Det første uddrag er fra interviewet med Søren, der senere bliver geografisk og socialt mobil.

\section{Uddrag 1 (1986)}

KMP: [...] nå men vi kom lidt væk fra det der sønderjyske Søren øh synes du der er behov for at du lærer rigsdansk

Søren: $\mathrm{mm}$

KMP: er det nødvendigt

Søren: næh ha ha

KMP: ja hvad vil du hvad var det du ville være bagefter

Søren: elektroniktekniker men så ska æ jo nok slå æwe til rigsdansk det troe $\mathfrak{x}$ næsten

elektroniktekniker men så skal jeg jo nok slå over til rigsdansk det tror jeg nasten

(sønderjyske ord og træk er fremhævede)

I første omgang svarer Søren grinende "næh" til, om han har behov for at lære rigsdansk. Men da han bliver spurgt om sine fremtidsplaner, ombestemmer han sig. Sørens klassekammerat Niels' fremtidsplaner kræver derimod efter hans egen opfattelse ikke rigsdansk.

\section{Uddrag 2 (1986)}

KMP: [...] kunne du tænke dig at lære at tale rent rigsdansk

Niels: nej hva ska man bruch det til når man bowe heneje nej bvad skal man bruge det til nair man bor bernede

KMP: nej det er da rigtigt nok hvad kunne du tænke dig at være bagefter

Niels: det er forskelle enten landbrugsmaskinmekaniker eller bu:n det er forskelligt enten landbrugsmaskinmekaniker eller bonde

Niels er i modsætning til Søren orienteret mod Sønderjylland og en uddannelse, der ikke indebærer social mobilitet. Han mener ikke, han 
skal bruge rigsdansk til noget, når han vil bo "hernede", dvs. i Sønderjylland, og når han enten vil være landbrugsmaskinmekaniker eller landmand. I uddragene kan man se, at Søren og Niels, til trods for at de er fuldstændig ens mht. alder, køn, etnicitet og social baggrund, har forskellige syn på, hvad de vil med livet, og hvilken sprogbrug der er passende i forhold til det.

Ud over deres geografiske og sociale orientering er det fælles for de mobile informanter, at de er opvokset i familier, der lægger vægt på uddannelse. På nær Eva fra Tinglev, hvis forældre er lærere, har ingen af de mobile informanters forældre boglige uddannelser; alligevel fremhæver de alle, at deres forældre bakkede op om deres skolegang. Det var vigtigt for forældrene, at de passede skolen, og at de fik en længere uddannelse, end de selv havde. En anden fællesnævner er, at alle mobile informanter har gået i skole i den lokale stationsby hele deres skolegang. Og det har formentlig haft betydning for deres sprogbrug. Kristensens undersøgelse viste således, at elever, der havde gået i skole i Vinderup hele deres skolegang, brugte markant færre dialektvarianter, end elever der havde gået på landsbyskolen Herrup Skole fra 1.-7. klasse (1980: 8). At sprogbrugen i stationsbyernes skole er mere standardnær, skyldes formodentlig den større sociale lagdeling, idet der som regel bor flere med længere uddannelser, såsom de lokale lærere samt den lokale læge, tandlæge og præst (Pedersen 2009a). Flere af de mobile informanter fortæller da også, hvordan de gennem skolen fik venner fra andre sociale lag og derigennem fik indblik i andre uddannelsesmæssige praksisser end i deres eget hjem. Venskaberne kan med andre ord have været med til at åbne deres øjne for muligheden for geografisk og social mobilitet. For de mobile informanter har skolegangen i stationsbyen desuden betydet, at de var omgivet af standardnær sprogbrug $i$ hverdagen $i$ en eller anden udstrækning, og at de fik brugsret til den på en anden måde end eleverne i omegnsskolerne. Blandt eleverne fra Herrup Skole blev det fx bemærket og opfattet som latterligt, når nogle af deres kammerater begyndte at tale "fint" ved overgangen til Vinderup Skole i 8. klasse (Monka 2013: 174). 


\section{FORHOLD OMKRING STED PÅVIRKER MOBILE INFOR- MANTERS SPROGBRUG}

I min ph.d.-afhandling argumenterer jeg for, at man bliver nødt til at se på en række forhold knyttet til sted for at forklare sprogbrugs- og sprogforandringsmønstre hos informanterne fra Odder, Vinderup og Tinglev. I forhold til denne artikels fokus på mobilitet nedtones gennemgangen og diskussionen af sted-begrebet; interesserede læsere henvises til mere omfattende analyser i Monka (2013) og (2014). Når jeg alligevel gerne vil redegøre kort for forskelle mellem de tre kommuner, er det fordi, det betyder noget for de mobile informanters sprogbrug og -forandring, hvor de flytter væk fra. De kvantitative analyser viste, at informanternes opvækststed har afgørende betydning for, hvor meget dialekt de har været omgivet af og har haft mulighed for at lære i deres opvækst. Desuden viser de kvalitative analyser, at opvækststedet også har betydning for, i hvilken udstrækning de mobile informanter er metasprogligt bevidste, og hvordan de bruger den lokale sprogbrug, efter de har været mobile.

Mine analyser viser, at der især er forskel mellem de mobile informanter fra Odder på den ene side og de mobile informanter fra Vinderup og Tinglev på den anden. Det kan forklares ved at foretage analyser af de tre steder vha. en humangeografisk tilgang til sted (Tuan 1991, Pred 1985). Andre sociolingvister, der er inspirerede af samme tilgang, har påpeget, at sprogforskere generelt har brug for at udvikle en mere nuanceret opfattelse af sted. Man skal som sociolingvist undgå at se den enkelte lokalitet som et geografisk punkt på landkortet og som en slags beholder for sprogbrug, sådan som bl.a. Auer (2013) påpeger, at det $\mathrm{i}$ vid udstrækning har været gjort i den hidtidige sprogforskning. I stedet skal der større fokus på historiske, politiske, økonomiske, socioøkonomiske og holdningsmæssige forhold, der kan være med til at forklare sprogbrugs- og sprogforandringsmønstre det enkelte sted (Britain 2002; Johnstone 2004, 2010; Horvath \& Horvath 2001). Samtidig bør man være opmærksom på, at opfattelsen af sted og dets betydning for sproget er i evig forandring og tilblivelse (Britain 2002), så når der fx sker kommunesammenlægninger eller andre centraliseringer, kan det have sproglige konsekvenser (Mæhlum 2010). 
Analyser af stedslige forhold knyttet til de tre kommuner viste nogle historiske og socio-økonomiske forskelle, der ifølge tidligere undersøgelser kan være med til at forklare, hvorfor dialektudtyndingen er mere fremskreden i Odder end i Vinderup og Tinglev (se fx I.L. Pedersen 2009a, 2009b). Odder ligger i et område, hvor industrialiseringen fra slutningen af 1800-tallet medførte social (og sproglig) lagdeling. Desuden er der kun $20 \mathrm{~km}$ til storbyen Århus, hvor man benytter nøjagtigt samme regionale træk som i Odder (Nielsen 1998). Hvad angår socio-økonomiske forhold, der kan påvirke dialektudtynding, så er der flere med en lang videregående uddannelse i Odder Kommune end landsgennemsnittet, og allerede i 1980'erne var det vanskeligt at finde informanter med landbrugsbaggrund (Nielsen \& Nyberg 1992: 53). Tilsvarende er der forhold omkring Vinderup og Tinglev Kommuner, der kan have virket dialektbevarende. De vigtigste er formentlig, at industrialiseringen begge steder først kom i gang fra 1920 og $i$ et begrænset omfang, samt at begge kommuner ligger i relativt stagnerende områder uden urbane centre i nærheden. Dertil kommer, at der i begge kommuner er flere ansat $i$ landsbrugssektoren og færre med en videregående uddannelse end landsgennemsnittet. Når sprogforandringen hos de bofaste informanter i Vinderup og Tinglev tager sig så forskelligt ud, skyldes det formentlig Sønderjyllands særlige historie og dialektens sammenkobling med den. Det, at Sønderjylland var under tysk styre fra 1864 til 1920, har haft betydning for dialekten på flere måder. Dels betød det, at indflydelsen fra standarddansk var mindre og senere end i resten af landet, og dels betød det, at brugen af sønderjysk indgik - og stadig indgår - i mange af de fortællinger, der er omkring det særlige ved landsdelen. Her fremstilles dialekten ofte som central for indbyggernes selvforståelse og identitet, og som noget der skal bevares. Og netop bevidsthed om den lokale sprogbrug og et ønske om at bevare den kan virke sprogbevarende (Hernes 2006).

Tidligere undersøgelser har vist, at mobile informanter generelt er mere metasprogligt bevidste end bofaste informanter (Johnstone 2010: 398). Det gælder også de mobile informanter i min undersøgelse. Men de kvalitative analyser viser, at de mobile informanter fra Odder er mindre metasprogligt bevidste om deres egen sprogbrug end de mobile informanter fra Vinderup og Tinglev. Det kan forklares med, at sprog- 
brugen det sted, de flytter væk fra, er regional og ikke dialektal; der er ganske enkelt mindre sproglig variation at være bevidst om. De mobile Odder-informanters sprogbrug er umarkeret i et stort område af Jylland og i den nærmeste storby Århus. Og selvom de benytter enkelte regionale varianter som OR og -ET i København, mødes de ikke af påstande om, at deres sprog er "uforståeligt", sådan som det ofte sker for dialekttalende fra fx Sønderjylland.

$\mathrm{Da}$ de første undersøgelser blev foretaget, var der en del dialekt at lære og blive opmærksom på både i Vinderup og Tinglev (Kristensen 1977, 1978; K.M. Pedersen 1986). Alligevel er der forskel på graden af metasproglig bevidsthed, og hvad dialekten bruges til af de mobile informanter fra de to kommuner. Og så er det ikke uventet sådan, at de kvindelige - og ikke de mandlige - informanter omtaler, hvilke sociale konsekvenser det kan have ikke at bruge lokal sprogbrug i visse situationer (Omdal 1994; Ivars 1986). Begge de mobile Vinderup-informanter ændrer ifølge eget udsagn kun sprogbrug i samtale med deres forældre og søskende. I interviewet viser det sig, at Mads ikke er så bevidst om sin egen sprogbrug, men han siger dog, at han taler "anderledes", når han taler med sin far; faktisk så meget, at hans kone synes, det er uforståeligt. Lisa derimod er bevidst om sin sprogbrug og fortæller, at hun taler "jysk" med sine forældre og brødre. Hun begrunder det med: "jeg synes det føles helt forkert at tale $\#^{7}$ tale anderledes til dem [...] fordi det er som om man forråder det man kommer fra". Hun taler altså jysk for at undgå at pege på det sociale skel, der er opstået mellem hende og familien, efter hun har været mobil.

Omtalen af skift til mere standardnær sprogbrug udgør en interessant forskel mellem informantgruppen fra Vinderup og den fra Tinglev. I Vinderup er det kun de mobile informanter, der efter eget udsagn praktiserer en eller anden form for kodeskift, og det hører til i privatsfæren. I Tinglev derimod foregår der både i 1986 og 2010 kodeskift i det offentlige rum. Og det at skifte sprogbrug er italesat som en sproglig praksis af både mobile og bofaste informanter, der alle har en holdning til, om de skifter mellem "sønderjysk" og "rigsdansk" eller taler enten den ene eller anden varietet hele tiden (K.M. Pedersen 1986; Monka 2013). Begge de mobile Tinglev-informanter omtaler disse skift i 2010.

\footnotetext{
7 \# angiver pause.
} 
Søren siger, at han skifter sprogbrug afhængig af samtalepartneren, og når han taler med sine forældre, siger han, at han "snakker sønderjysk som jeg gjorde dengang". Eva bruger efter eget udsagn kun sønderjysk i udvalgte situationer i 2010. Hun bruger det "for sjov" sammen med sine søskende "hvis jeg skal pjatte med sproget eller lege med sproget", dvs. som en ekstra sproglig ressource. At hun ikke bruger det i samtale med sin mor skyldes, at hun fortrinsvis har talt "rigsdansk" i sit barndomshjem, sønderjysk var noget, hun lærte af sine kammerater ${ }^{8}$. For den symbolværdi der tillægges dialekten, er det interessant, hvad hun også bruger dialekten til. Hun fortæller, at den eneste, hun konsekvent taler sønderjysk med i 2010, er sin svoger. Det gør hun, så han ikke skal opfatte hende som "sådan lidt fin eller sådan ikke sådan lidt snobbetagtig". Desuden bruger hun sønderjysk i butikker i Sønderjylland: "fordi så tænker jeg nå så kan de høre jeg er herfra”. Eva bruger altså ligesom Lisa fra Vinderup dialekten for at undgå at påpege sociale skel mellem sig selv og samtalepartnere. Men i modsætning Lisa bruger hun også dialekten over for fremmede, for at vise at hun hører til. Det sidste kan formentlig forklares vha. de ovennævnte forhold knyttet til Sønderjylland som sted, hvilket betyder, at dialekten tillægges større prestige.

\section{KONKLUSION}

Min undersøgelse bekræfter tidligere mobilitetsstudiers fund og viser, at geografisk og social mobilitet hænger sammen med mere standardnær sprogbrug. Men fordi studiet er et panelstudie i virkelig tid af både mobile og bofaste informanters sprogbrug, kan jeg også besvare nogle hidtil ubesvarede spørgsmål om sammenhænge mellem mobilitet og sprogforandring. Mest overraskende er det, at de informanter, der ender med at blive geografisk og socialt mobile, taler mindre lokalt end bofaste informanter, allerede før de er mobile. Desuden viser analyserne tydeligt, at mobilitet ikke er den eneste årsag til sprogforandring. I Odder og Vinderup er det således i de bofaste informanters sprogbrug, den største sprogforandring finder sted. De kvantitative resultater viser endvidere, at de mobile fra Odder har bevaret enkelte regionale

8 Der findes både gamle og nye interviewoptagelser, hvor hun benytter alle de sønderjyske variable, der indgår i tabel 4 på nær IKKE. 
varianter i de nye interview, imens de mobile fra Vinderup og Tinglev ikke bruger nogen af de dialektale varianter. Man kan altså godt være geografisk og socialt mobil i Danmark og bevare få regionale varianter, men det samme lader ifølge min undersøgelse ikke til at være tilfældet for dialektvarianter.

Undersøgelsens kvalitative analyser forsøger at forklare de mobile informanters sprogbrug og sprogforandringsmønstre. Analyserne peger på, at en af de mest interessante forskelle mellem mobile og bofaste informanter er forskelle i deres geografiske og sociale orientering $i$ barnog ungdommen. Det viser sig, at de senere mobile informanter er mere mentalt mobile. De er i højere grad end de bofaste informanter orienteret mod urbane steder og højere uddannelser. De kvalitative analyser peger også på, at der er vigtige sammenhænge mellem de mobiles sprogbrug og -forandring og det sted, de flytter væk fra. Vinderup- og Tinglev-informanterne, der er vokset op omgivet af mere dialekt end Odder-informanterne, er således mere bevidste om deres egen sprogbrug. De omtaler alle fire, at de kan ændre sprogbrug til en mere lokal variant. De mobile fra Vinderup gør det kun med den nærmeste familie, mens dem fra Tinglev gør det, når andre taler sønderjysk til dem, eller som Eva i lokale butikker for at vise, hun er fra landsdelen. Forskellen $i$ brug af den lokale sprogbrug i Vinderup og Tinglev kan ifølge mine analyser forklares med, at kodeskift var mere udbredt i Tinglev, da informanterne voksede op, samt at der er en særlig symbolsk værdi knyttet til den sønderjyske dialekt. I en del situationer kan det betale sig at bruge den også uden for familien. Men Sørens sprogforandring fra overvejende brug af dialektvarianter i 1986 til ingen i 2010, selvom han er blevet boende i det sønderjyske dialektområde, viser samtidig, at sønderjysk lige som andre dialekter ofte ikke duer i hverdagen, når man har været socialt mobil.

Malene Monka

Nordisk Forskningsinstitut

Københavns Universitet

monka@hum.ku.dk 


\section{LITTERATUR}

Adey, P. 2009. Mobility. Milton Park: Routledge.

Andersen, H. S. 2010. När teltpalene rykekes op. Geografisk mobilitet i Danmark og dens årsager. Aalborg, Center for Bolig og Velfærd.

Andersson, R. \& M. Thelander. 1994. Internal migration, biography formation, and linguistic change. B. Nordberg (red.), The Sociolinguistics of Urbanization: The Case of the Nordic Countries. 51-86. Berlin: de Gruyter.

Auer, P. 2013. The geography of language: Steps toward a new approach. FRAGL 16. portal.uni-freiburg.de/sdd/fragl/2013.16. (Tilgået februar 2014).

Bailey, G. 2002. Real and apparent time. J. K. Chambers, P. Trudgill \& N. SchillingEstes (red.), The Handbook of Language Variation and Change. 312-331. Oxford: Oxford University Press.

Bowie, D. F. 2000. The effect of geographic mobility on the retention of a local dialect. Ph.d.afhandling. Pennsylvania: University of Pennsylvania.

Britain, D. 2002. Space and spatial diffusion. J. K. Chambers, P. Trudgill \& N. SchillingEstes (red.), The Handbook of Language Variation and Change. 603-637. Blackwell.

Britain, D. 2013. The role of mundane mobility and contact in dialect death and dialect birth. D. Schreier \& M. Hundt (red.), English as a Contact Language. 165-181. Cambridge: Cambridge University Press.

Chambers, J. K. 2002. Dynamics in dialect convergence. Journal of Sociolinguistics 6(1). 117-130.

Cresswell, T. 2006. On the Move: Mobility in the modern western world. London: Routledge. Eckert, P. 2000. Linguistic Variation as Social Practice. Oxford: Blackwell.

Gregersen, F., J.N. Jørgensen, T. Kristiansen \& I.L. Pedersen. 2005. Project for the Danish National Research Foundation Centre for Language Change in Real Time (LANCHART): Denmark 1900-2000 as an example. lanchart.hum.ku.dk/aboutlanchart/box_projectdescription (Tilgået oktober 2015).

Gregersen, F. \& T. Kristiansen (red.). 2015. Hvad ved vi nu - om danske talesprog. København: Sprogforandringscentret.

Hernes, R. 2006. Talemål $i$ endring? Ein longitudinell studie av talemålsutvikling og språkleg royndomsoppfatning hjå ungdomar $i$ Os. Dr.art.-afhandling. Bergen: Universitetet $\mathrm{i}$ Bergen. hdl.handle.net/1956/1927 (Tilgået oktober 2015).

Hårstad, S. 2010. Unge språkbrukere i gammel by: En sosiolingvistisk studie av ungdomstalemål i Trondheim. Ph.d.-afhandling. Trondheim: Norges Teknisk-Naturvitenskapelige Universitet, NTNU. hdl.handle.net/11250/243706 (Tilgået oktober 2015).

Horvath, B. M. \& R. J. Horvath. 2001. A multilocality study of a sound change in pro- 
gress: The case of /1/ vocalization in New Zealand and Australian English. Language Variation and Change 13(1). 37-57.

Ivars, A.-M. 1986. Från Österbotten til Sörmland. En undersöknig av emigration och språklig anpassning. Studier $i$ Nordisk Filologi 66. Helsingfors: Svenska litteratursällskapet i Finland.

Johnstone, B. 2004. Place, globalization, and linguistic variation. C. Fought (red.), Sociolinguistic Variation - Critical Reflections. 65-83. Oxford: Oxford University Press.

Johnstone, B. 2010. Indexing the local. N. Coupland (red.), Handbook of Language and Globalization. 386-405. Chichester: Wiley-Blackwell.

Kerswill, P. 1985. A Sociolinguistic Study of Rural Immigrants in Bergen, Norway. Cambridge: University of Cambridge.

Kerswill, P. 1994. Dialects Converging: Rural Speech in Urban Norway. Oxford: Oxford University Press.

Kerswill, P. \& A. Williams. 2000. Creating a New Town koine: Children and language change in Milton Keynes. Language in Society 29(1). 65-115.

Kristensen, K. 1977. Variationen i vestjysk stationsbymål. En kvantitativ sociolingvistisk dialektundersøgelse i Vinderup, Ringkøbing Amt. Dialektstudier 4(1). 29109.

Kristensen, K. 1979. Kvantitative sprogblandingsstudier. Dialektstudier 4(2). 161-236.

Kristensen, K. 1980. Situationsafhængig sprogbrug hos vestjyske skoleelever. Danske Folkemål 22(2). 29-124.

Kristiansen, T. 2009. The macro-level social meaning of late-modern Danish accents. Acta Linguistica Hafniensia 41. 167-192.

Labov, W. 1967. The effect of social mobility on linguistic behavior. S. Lieberson (red.), Explorations in Sociolinguistics. 58-75. Bloomington: Mouton \& Co.

Maegaard, M. 2007. Udtalevariation og -forandring i københavnsk - en etnografisk undersøgelse af sprogbrug, sociale kategorier og social praksis blandt unge på en københavnsk folkeskole. Ph.d.-afhandling. København: Københavns Universitet

McIlvenny, P., M. Broth \& P. Haddington. 2009. "Communicating place, space and mobility. Journal of Pragmatics 41(10). 1879-1886.

Mees, I. M. \& B. Collins. 1999. Cardiff: a real-time study of glottalisation. P. Foulkes \& G. Docherty (red.), Urban Voices - Accent studies in the British Isles. 185-202. London: Arnold.

Milroy, L. 1980. Language and Social Networks. Oxford: Blackwell.

Monka, M. 2013. Sted og sprogforandring - en undersøgelse af sprogforandring i 
virkelig tid hos mobile og bofaste informanter fra Odder, Vinderup og Tinglev. Ph.d.-afhandling. Danske Talesprog 13: 1-336.

Monka, Malene 2014. Sproget afhænger af stedet - om sprogforandring i virkelig tid i Jylland. Mål og Minne, 106(2) 92-130.

Munk, M.D. 2003. Social mobilitet. Social mobilitet i Danmark - set $i$ et internationalt perspektiv. Socialforskningsinstituttet. Arbejdspapir 9.

Mæhlum, B. 1986. Språklige variasjonsmonstre hos innflyttere i Oslo. Oslo: Novus.

Mæhlum, B. 1992. Dialektal sosialisering - En studie av barn og ungdoms språklige strategier $i$ Longyearbyen på Svalbard. Oslo: Novus.

Mæhlum, B. 2010. Language and social space. P. Auer \& J.E. Schmidt (red.), Language and Space. 18-34. Berlin: De Gruyter Mouton.

Nielsen, B. J. 1998. Talesprogsvariationen i Århus - en sociolingvistisk redegørelse og en sammenligning med sproget i Odder. Danske Folkemål 40. 51-78.

Nielsen, B. J. \& M. Nyberg. 1988. Talesprogsvariationen i Odder kommune. En foreløbig rapport. Danske Folkemål 30. 31-88.

Nielsen, B. J. \& M. Nyberg. 1989. Talesprogsvariationen i Odder kommune. En foreløbig rapport. II. Yngre rigsmålstræk. Danske Folkemål 31. 119-153.

Nielsen, B. J. \& M. Nyberg. 1992. Talesprogvariation i Odder kommune. I. Lokalsprog og rigsmål i sociolingvistisk belysning. Danske Folkemål 34. 45-202.

Nielsen, B. J. \& M. Nyberg. 1993. Talesprogsvariation i Odder kommune. II. Yngre og ældre rigsmålsformer i sociolingvistisk belysning. Danske Folkemål 35. 249-348.

Nielsen, B.J. \& K.M. Pedersen. 1991. Danske Talesprog. København: Gyldendal.

Nyberg, M. 1991. Unge sønderjyders rigsmålstilegnelse. Danske Folkemål 33. 159-168.

Omdal, H. 1994. Med språket på fytttefot. Språkvariasjon og språkstrategier blant setesdolere $i$ Kristiansand. Doktorafhandling. Uppsala: Institutionen för nordiska språk.

Pedersen, I. L. 1994. Linguistic variation and composite life modes. B. Nordberg (red.), The Sociolinguistics of Urbanization: The Case of the Nordic Countries. 87-115. Berlin: De Gruyter.

Pedersen, I. L. 2009a. Standardtalesprogets tilblivelse og rolle i Danmark. Norsk Lingvistisk Tidsskrift 27(1). 159-177.

Pedersen, I. L. 2009b. 500 års landbohistorie spejlet i talesproget - De danske dialekters død i fire akter. Landbobistorisk tidsskrift 2. 42-71.

Pedersen, K. M. 1986. Modet mellem sprogene i den dansk-tyske granseregion. En-, to- eller flersprogede born i Sonderjylland. Aabenraa: Institut for Grænseregionsforskning.

Pedersen, K. M. 2004. Mødet mellem kulturerne og sprogene i den dansk-tyske grænseregion - en model for et interkulturelt samfund? PLUK 1. 43-44. 
Petersen, K. T. 2013. Lokalt regionalsprog eller regionalt rigssprog - en undersøgelse af Århus-dansk. NyS 45. 9-47.

Pred, A. 1985. The social becomes the spatial, the spatial becomes the social: Enclosures, social changes and the becoming of places in Skåne. D. Gregory \& J. Urry (red.), Social Relations and Spatial Structures. 337-365. London: Macmillan.

Ringgaard, K. 1960. Vestjysk stod. Aarhus: Universitetsforlaget i Aarhus.

Røyneland, U. 1994. Når bygdemål moter bymål. Ein individsentreret eksempelstudie av fire sunnmoringar $i$ Oslo. Kandidat-speciale. Oslo: Oslo Universitet.

Schøning, S. \& I. L. Pedersen. 2009. Vinderup in real time - a showcase of dialect levelling. M. Dufresne, F. Dupuis \& E. Vocaj (red.), Historical Linguistics 2007: Selected papers from the 18th International Conference on Historical Linguistics, Montreal, 6-11 August 2007. 233-244. Amsterdam: John Benjamins.

Solheim, R. 2006. Språket $i$ smeltegryta. Sosiolingvistiske utviklingsliner $i$ industrisamfunnet Hoyanger. Doktorafhandling. Trondheim: Norges Teknisk-Naturvitenskapelege Universitet, NTNU.

Thelander, M. 1979. Språkliga variationsmodeller tillämpade på nutida Burträsktal. Almqvist \& Wiksell International: Stockholm.

Thelander, M. 1985. Från Blåknut till brakknut. Om proviensella drag i flyttares språk. Nysvenska studier 63. 5-126.

Tuan, Yi-Fu 1991. Language and the making of place: A narrative-descriptive approach. Annals of the Association of American Geographers 81(4). 684-696.

Urry, J. 2007. Mobilities. Cambridge: Polity Press. 